\title{
Fully Synthetic Carbohydrate HIV Antigens Designed on the Logic of the 2G12 Antibody
}

Isaac J. Krauss, Joseph G. Joyce, Adam C. Finnefrock, Hong C. Song, Vadim Y. Dudkin ${ }^{1}$, Xudong Geng ${ }^{2}$, J. David Warren ${ }^{3}$, Michael Chastain, John W. Shiver and Samuel J. Danishefsky*

\section{Supporting Information}

\section{General Information:}

Analytical Equipment: ${ }^{1} \mathrm{H}$ - and ${ }^{13} \mathrm{C}$ NMR spectra were recorded on a Bruker AMX-400, a Bruker DRX-500, or a Bruker AVII+-600 spectrometer in $d_{6}$-DMSO or $\mathrm{D}_{2} \mathrm{O}$. Chemical shifts ( $\delta$-values) are reported in ppm with residual undeuterated $\mathrm{HCD}_{2}\left(\mathrm{SO}_{2} \mathrm{CD}_{3}\right.$ as the internal standard (referenced to $2.51 \mathrm{ppm}$ ) or in the case of $\mathrm{D}_{2} \mathrm{O}$, to an external standard of 3-(Trimethylsilyl)-1-propanesulfonic acid, sodium salt. Coupling constants (J) (H,H) are given in $\mathrm{Hz}$, spectral splitting patterns are designated as singlet (s), doublet (d), triplet (t), quadruplet (q), quintet (qunit), multiplet or more overlapping signals (m), apparent (app), broad signal (br). Low resolution mass spectra (electrospray ionization) were acquired on a ZQ Micromass spectrometer. Samples were introduced by direct infusion. In the case of LC/MS, analysis was performed with a Waters Alliance analytical LC system in tandem with the Micromass ZQ. All HPLC was run with TFA (trifluoroacetic acid)-buffered eluents: $\mathrm{A}=.05 \% \mathrm{v} / \mathrm{v}$ TFA/Water, $\mathrm{B}=.04 \% \mathrm{v} / \mathrm{v}$ TFA/Acetonitrile.

DMSO was purchased from Aldrich (Anhydrous grade) and used without further purification. DIEA (iPr $2 \mathrm{NEt})$ was freshly distilled from $\mathrm{CaH}_{2}$. DBU (Diazabicycloundecene) and Piperidine were purchased from Aldrich and used without further purification. HATU ( $O$-(7-azabenzotriazol-1-yl)-N,N,N',N'-tetramethyluronium hexafluorophosphate) was purchased from GenScript and used without further purification. Peptide synthesis resins and Fmoc-amino acids were purchased from NovaBiochem.

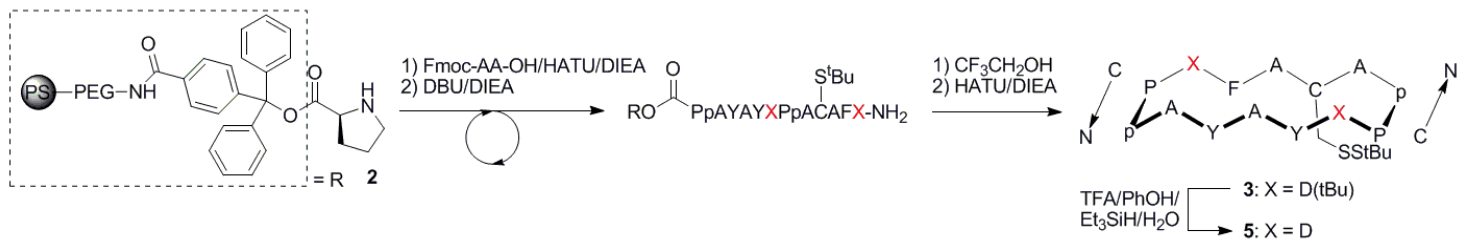

Cyclic peptide 5: NovaSyn TGT resin (purchased from NovaBiochem) was chlorinated, then esterified with Fmoc-Pro-OH, and then immediately Fmoc-deprotected according to a literature procedure. ${ }^{4}$ Fmoc quantitation of the resin prior to deprotection indicated a loading of $.160 \mathrm{mmol} / \mathrm{g}$. $.999 \mathrm{~g}$ of this resin (2) was subjected continuous flow automated peptide synthesis. For coupling steps, resin was treated with with a 3-fold excesses of HATU and Fmoc amino acids in DIEA/DMF, and for deblocking, a solution of $2 \%$

\footnotetext{
${ }^{1}$ Current address: Merck \& Co., Department of Medicinal Chemistry, West Point, PA 19486.

${ }^{2}$ Current address: Novartis Institute for Biomedical Research, Inc., Cambridge, MA 02139.

${ }^{3}$ Current address: Weill Medical College of Cornell University, New York, NY 10021.

${ }^{4}$ Fmoc Solid Phase Peptide Synthesis: A Practical Approach. Ed. Chan, W. C. and White, P. D. Oxford University Press, New York, 2000. pp 50 and 217.
} 
Piperidine / 2\% DBU in DMF was used. The amino acids used were, in order of synthesis, Fmoc-D-Pro-OH, Fmoc-Ala-OH, Fmoc-Tyr(tBu)-OH, Fmoc-Ala-OH, Fmoc$\operatorname{Tyr}(\mathrm{tBu})-\mathrm{OH}$, Fmoc-Asp(tBu)-OH, Fmoc-Pro-OH, Fmoc-D-Pro-OH, Fmoc-Ala-OH, Fmoc-Cys(StBu)-OH, Fmoc-Ala-OH, Fmoc-Phe-OH, Fmoc-Asp(tBu)-OH. The resin was then transferred to a manual peptide synthesis vessel and treated with a cleavage solution of $10 \mathrm{~mL}$ of $20 \%$ trifluoroethanol in dichloromethane for 2 hours. The beads were filtered, rinsed with another $10 \mathrm{~mL}$ cleavage solution, filtered again, and then treated for another 2 hours with $10 \mathrm{~mL}$ of cleavage solution. This process was repeated for a total of 3 2-hour cleavage cycles, and the combined filtrate was concentrated in vacuo to afford $\sim 260 \mathrm{mg}$ crude linear protected peptide as a colorless glass. (ESI MS analysis showed predominantly the desired product peak, $1809.9(\mathrm{M}+\mathrm{H}))$ This material was redissolved in $100 \mathrm{~mL}$ of $1 \% \mathrm{v} / \mathrm{v}$ DIEA in DMF. HOAt $(65.9 \mathrm{mg}, .484 \mathrm{mmol}, 3$ equiv.) was added, followed by HATU (184mg, .484mmol, 3 equiv.). After 1 hour, the solvent was removed in vacuo (using a rotary evaporator, $\sim 1 \mathrm{~mm} \mathrm{Hg}, 30^{\circ} \mathrm{C}$ ), affording the crude cyclic protected peptide contaminated with HATU/HOAt-derived byproducts. (ESI MS analysis showed predominantly the desired product peak, $1791.9(\mathrm{M}+\mathrm{H}))$. This material was then redissolved in $15 \mathrm{~mL}$ of $87.5 \%$ TFA / $5 \%$ water / $5 \%$ phenol / $2.5 \%$ triethylsilane $(\mathrm{v} / \mathrm{v} / \mathrm{m} / \mathrm{v})$ solution and stirred for 30 minutes. Solvent was removed in vacuo, then the residue was triturated with $25 \mathrm{~mL}$ diethyl ether 4 times to afford crude peptide $\mathbf{5}$. This was purified in four batches by preparative reverse-phase HPLC (on a 41 x 250mm Varian Microsorb C18 Dynamax, $60 \AA$ pore size, $8 \mu \mathrm{M}$ particle size column) using a gradient of 20-50\% B buffer (see General Info) over $40 \mathrm{~min}$, flow rate $80 \mathrm{~mL} / \mathrm{min}, 230 \mathrm{~nm} \mathrm{UV}$ detection. The peak with retention time of 19.9 minutes was collected and lyophilized to afford $160 \mathrm{mg} 5$ (64\% yield based on proline-loaded resin 2). Post-purification analytical LC/ESI MS analysis showed a clean product spectrum with a base peak of $1567.7(\mathrm{M}+$ $\mathrm{H})$ and $1589.7(\mathrm{M}+\mathrm{Na}) \mathrm{HNMR}\left(600 \mathrm{MHz}, \mathrm{d}_{6}-\mathrm{DMSO}\right) \delta$ (selected resonances) $\mathrm{N}-\mathrm{H}$ : 7.37(d, $J=9.2 \mathrm{~Hz}, 1 \mathrm{H}), 7.43(\mathrm{~d}, J=9.1 \mathrm{~Hz}, 1 \mathrm{H}), 8.23(\mathrm{~d}, J=8.0 \mathrm{~Hz}, 1 \mathrm{H}), 8.30-8.40$ (m, $3 \mathrm{H}), 8.48(\mathrm{~d}, J=8.5 \mathrm{~Hz}, 1 \mathrm{H}), 8.56(\mathrm{~d}, J=8.0 \mathrm{~Hz}, 1 \mathrm{H}), 8.62(\mathrm{~d}, J=8.0 \mathrm{~Hz}, 1 \mathrm{H}), 8.73(\mathrm{~d}$, $J=8.7 \mathrm{~Hz}, 1 \mathrm{H})$; $\mathrm{C}-\mathrm{H}_{\alpha}: 4.27-4.35(\mathrm{~m}, 2 \mathrm{H}), 4.47-4.61(\mathrm{~m}, 4 \mathrm{H}), 4.70-4.75(\mathrm{~m}, 2 \mathrm{H}), 4.78-$ $4.87(\mathrm{~m}, 2 \mathrm{H}), 4.90-4.93(\mathrm{~m}, 1 \mathrm{H}), 4.93-5.00(\mathrm{~m}, 2 \mathrm{H}), 5.01-5.06(\mathrm{~m}, 1 \mathrm{H})$.

Purified peptide 5: (UV detection top, MS detection bottom, MS spectrum, right $\mathrm{M}+\mathrm{H}, \mathrm{M}$ $+\mathrm{Na})$ :

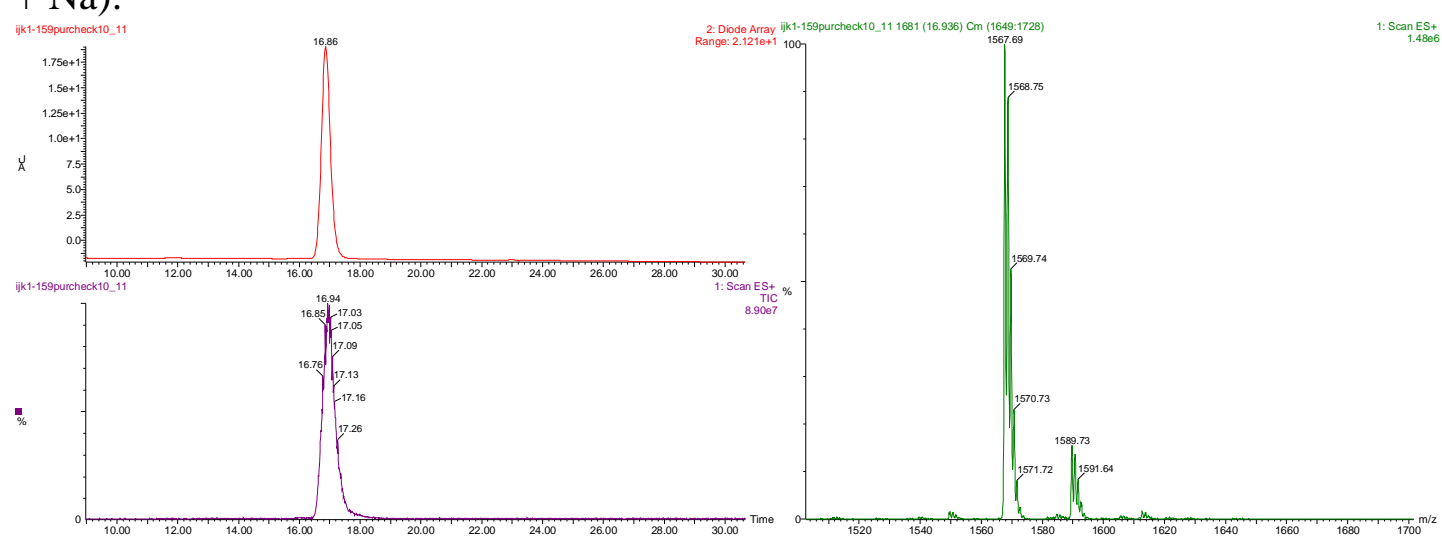


$600 \mathrm{MHz}$ spectrum of 5 in $\mathrm{d}_{6}$-DMSO:

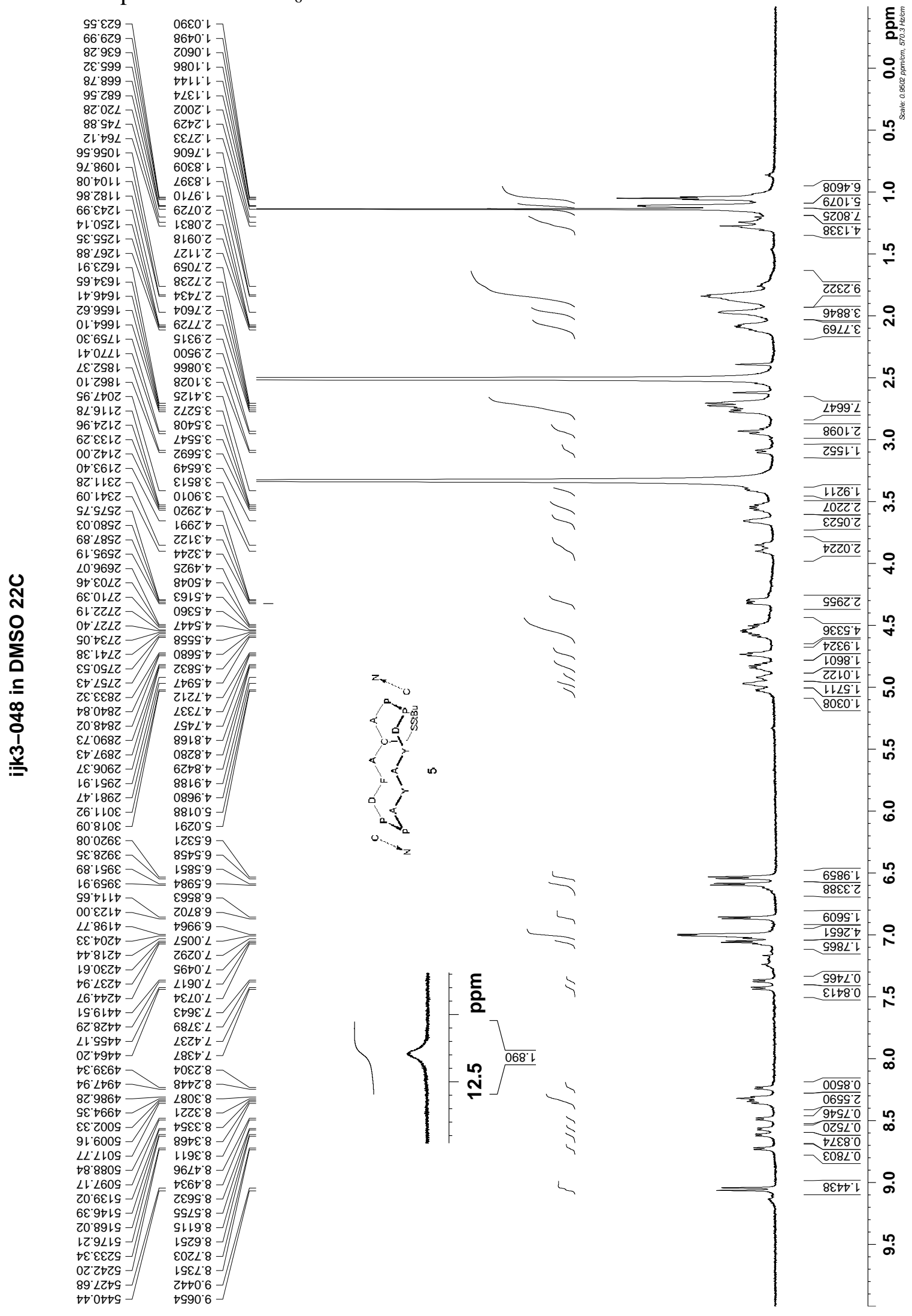




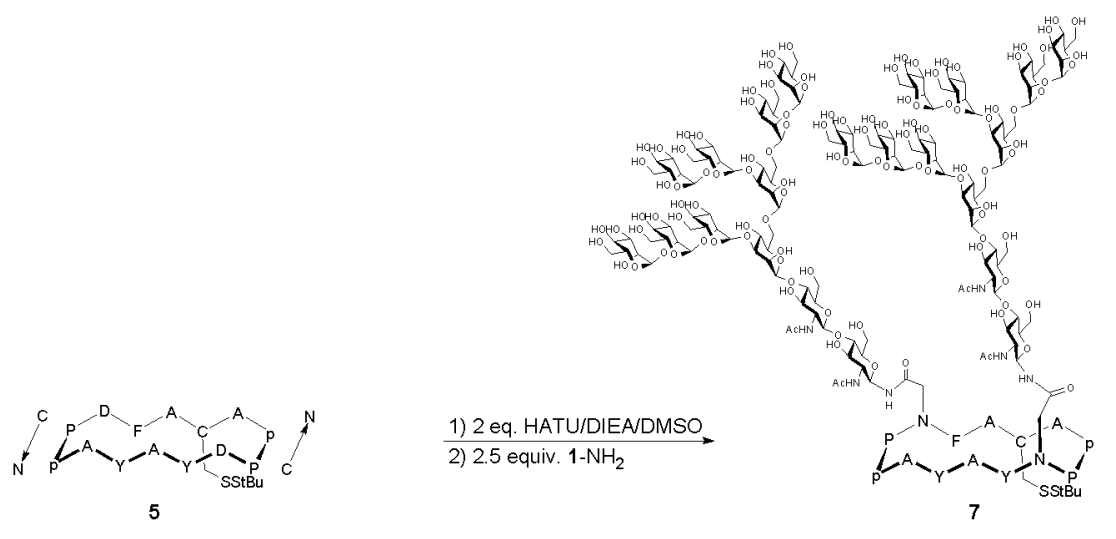

Divalent Glycopeptide 7: Solutions of each reaction participant were prepared with a stir bar in flame-dried vials under argon as follows: Peptide 5 (10 mg, $6.4 \mu \mathrm{mol}$, dissolved in

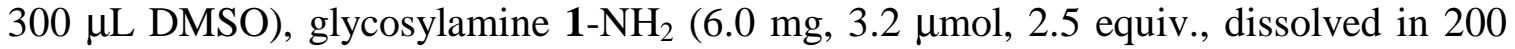
$\mu \mathrm{L}$ DMSO), HATU (10 mg dissolved in $500 \mu \mathrm{L}$ DMSO). $6.7 \mu \mathrm{L}$ of dry $\mathrm{iPr}_{2} \mathrm{NEt}(5.0 \mathrm{mg}$, $38 \mu \mathrm{mol}, 6.0$ equiv with respect to whole peptide solution) was added to the vial containing peptide 5 , followed by $274 \mu \mathrm{L}$ of the HATU solution $(8.14 \mu \mathrm{mol}, 2.2$ equiv. with respect to whole peptide solution), producing a strong yellow color. Within 30 seconds, $115 \mu \mathrm{L}(1.3 \mu \mathrm{mol})$ of this activated peptide solution was transferred to the rapidly stirred vial containing the solution of glycosylamine 1- $\mathrm{NH}_{2}$. After 1 hour, LC/MS analysis of the crude reaction mixture $(20-50 \% \mathrm{~B}$ over $40 \mathrm{~min}$, same solvent system as above, Microsorb C18, 300-5, 2 x 150mm, .2mL/min) showed mostly the divalent glycopeptide (RT $13 \mathrm{~min}$ ), with smaller amounts of mono-coupled products (RT 15-18 min). The crude reaction mixture was diluted with $\sim 300 \mu \mathrm{L}$ of $10 \% \mathrm{~B}$ HPLC buffer and injected directly onto preparative reverse-phase HPLC using a gradient of 21-36\% B over 45 minutes, flow rate $16 \mathrm{~mL} / \mathrm{min}$. The column used was a 21.4 x $250 \mathrm{~mm}$ Varian Microsorb C18 Dynamax column, $300 \AA$ pore size, $5 \mu \mathrm{M}$ particle size. Retention time for divalent glycopeptide 7 was 22 minutes, and monovalent product was collected at 31 minutes. Post-purification analytical LC/MS anlysis of the peak at 22 minutes showed a clean product chromatogram and MS spectrum with base peaks of $2648.8(\mathrm{M}+2 \mathrm{H}$, [2648.0 calc]) and $1765.0(\mathrm{M}+3 \mathrm{H}$ [1765.7 calc]). Lyophilization of these fractions yielded $4.7 \mathrm{mg}(70 \%)$ of $7 .{ }^{1} \mathrm{HNMR}\left(500 \mathrm{MHz}, \mathrm{D}_{2} \mathrm{O}\right.$, selected resonances): $\delta$ anomeric protons: $(5.02,5.04,8 \mathrm{H}$ together), $5.13(\mathrm{~s}, 2 \mathrm{H})(5.30,5.33,4 \mathrm{H}$ together $), 5.40(\mathrm{~s}, 2 \mathrm{H})$.

LC of crude reaction mixture (left), and LC/MS after purification (right, 20-35\% gradient):
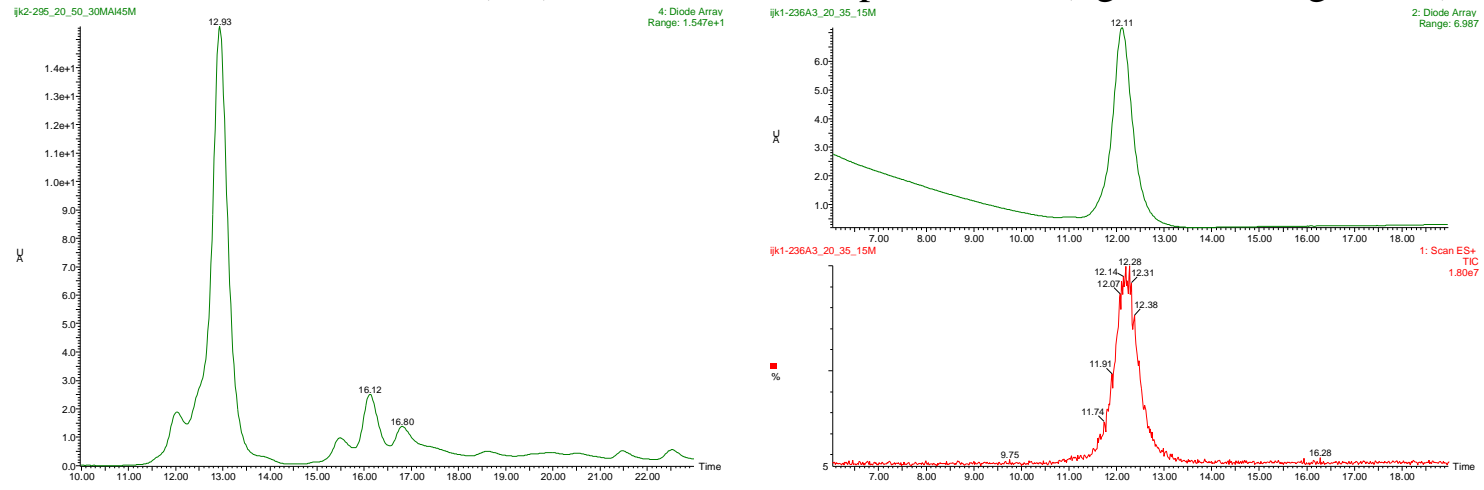
ESI-MS of 7 (double ion):
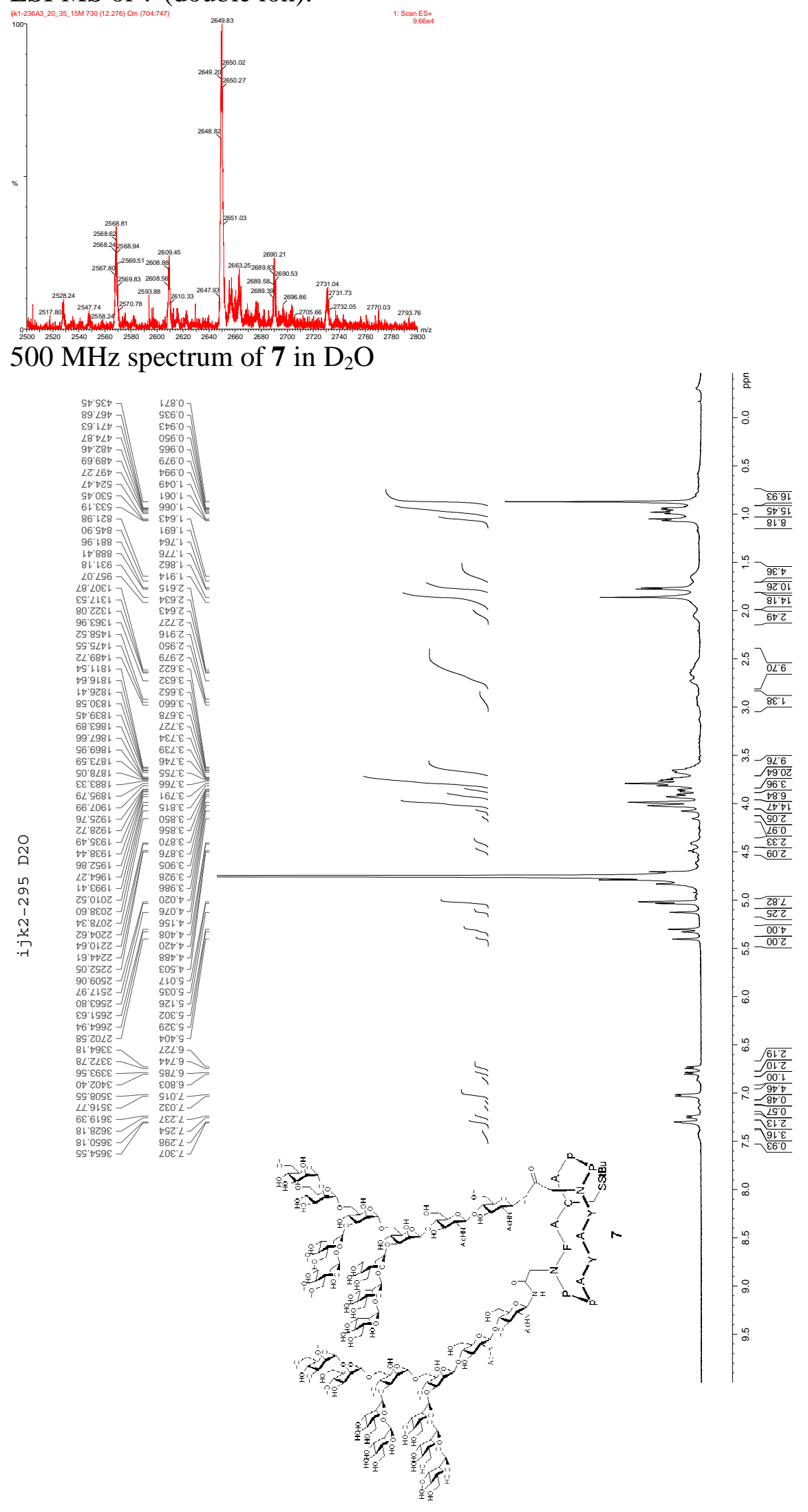


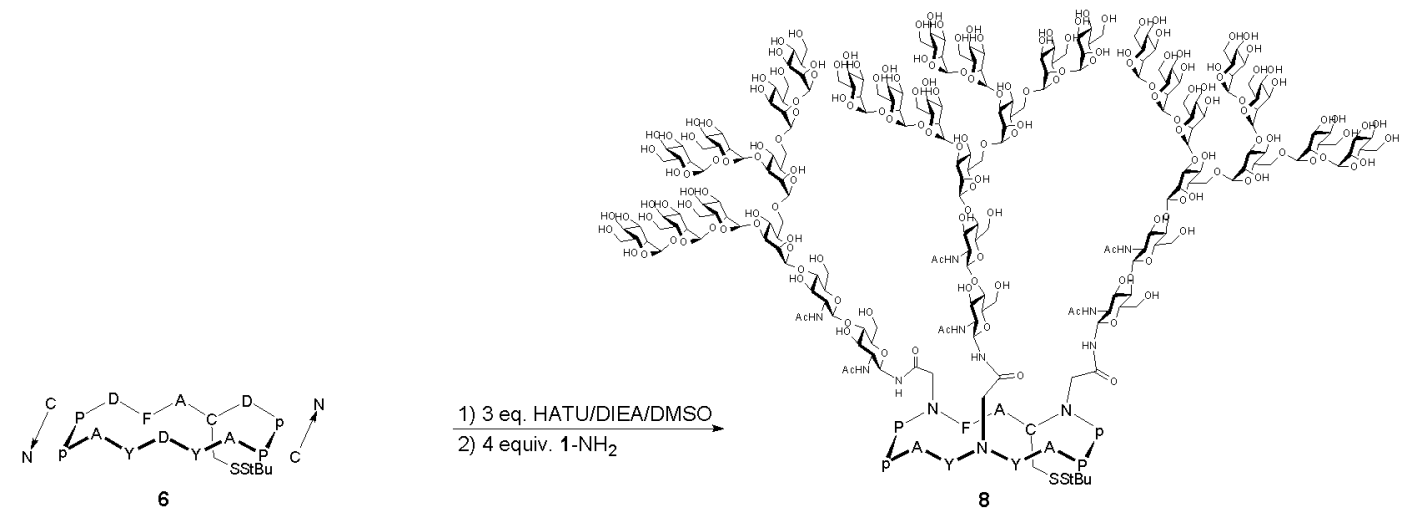

Trivalent Glycopeptide 8: Solutions of each reaction participant were prepared with a stir bar in flame-dried vials under argon as follows: Peptide 6 (obtained in a manner analogous to the preparation of 5): $2.5 \mathrm{mg}, 1.6 \mu \mathrm{mol}$, dissolved in $100 \mu \mathrm{L}$ DMSO; glycosylamine 1- $\mathrm{NH}_{2}: 1.0 \mathrm{mg}, .53 \mu \mathrm{mol}, 2.5$ equiv., dissolved in $20 \mu \mathrm{L}$ DMSO; HATU: $5 \mathrm{mg}$ dissolved in $200 \mu \mathrm{L}$ DMSO. $2.4 \mu \mathrm{L}$ of dry $\mathrm{iPr}_{2} \mathrm{NEt} 1.8 \mathrm{mg}, 14 \mu \mathrm{mol}$, (9.0 equiv with respect to whole peptide solution) was added to the vial containing peptide 6 , followed by $96 \mu \mathrm{L}$ of the HATU solution $(5.1 \mu \mathrm{mol}, 3.3$ equiv. with respect to whole peptide solution), producing a strong yellow color. Within 30 seconds, $16 \mu \mathrm{L}(.13 \mu \mathrm{mol})$ of this activated peptide solution was transferred to the rapidly stirred vial containing the solution of glycosylamine 1- $\mathrm{NH}_{2}$. After 2.5 hours, LC/MS analysis of the crude reaction mixture (20-50\% B over $40 \mathrm{~min}$, see General Info for solvent definitions, Microsorb C18, $300-5,2 \times 150 \mathrm{~mm}, .2 \mathrm{~mL} / \mathrm{min}$ ) showed mostly the trivalent glycopeptide (RT $12 \mathrm{~min}$ ), with smaller amounts of di- and mono-coupled products (RT 13 and 15 min). The crude reaction mixture was diluted with $\sim 300 \mu \mathrm{L}$ of $10 \%$ B HPLC buffer and injected directly onto preparative reverse-phase HPLC using a gradient of $10-20 \%$ B over 10 minutes, followed by $20-45 \%$ B over 30 minutes, flow rate $16 \mathrm{~mL} / \mathrm{min}$. The column used was a 21.4 x 250mm Varian Microsorb C18 Dynamax column, $300 \AA$ pore size, $5 \mu \mathrm{M}$ particle size. Retention time for trivalent glycopeptide $\mathbf{8}$ was 28 minutes, and divalent product was collected at 31 minutes. Lyophyilzation of the fraction at 28 minutes afforded $.45 \mathrm{mg}$ of product (45\%). MS analysis of this material showed signals at $3624.1(\mathrm{M}+3 \mathrm{Na}$ [3623.8 calc]) and $2424.7(\mathrm{M}+3 \mathrm{Na}$ [2423.5 calc]):

LC of crude reaction mixture (left), double ion of $\mathbf{8}$ (middle), triple ion (right):
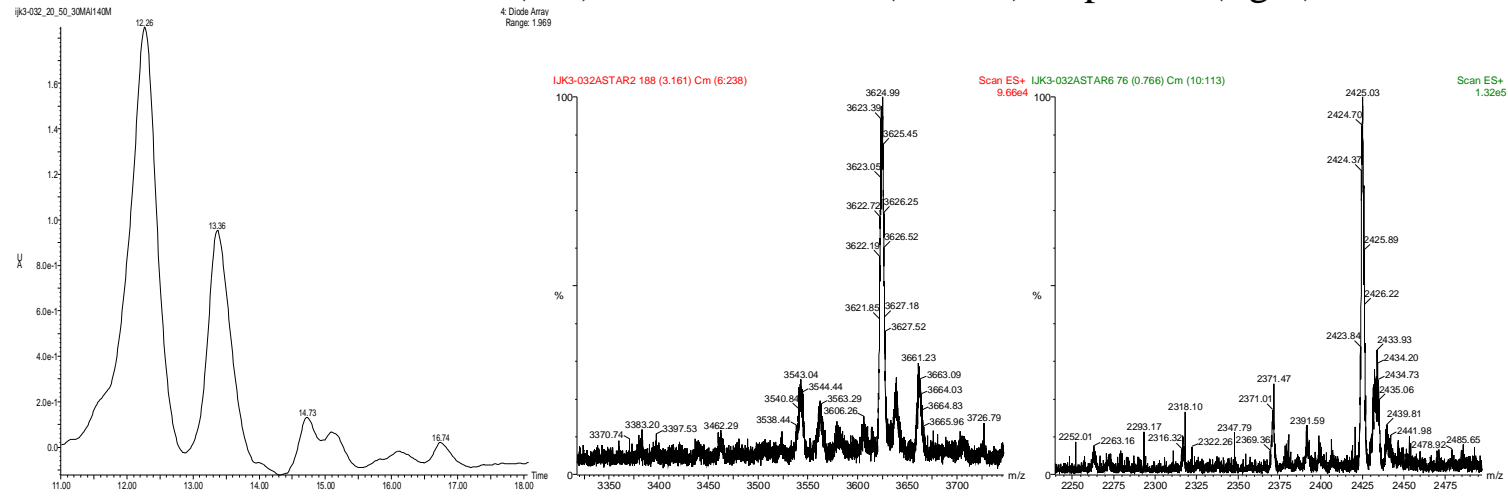

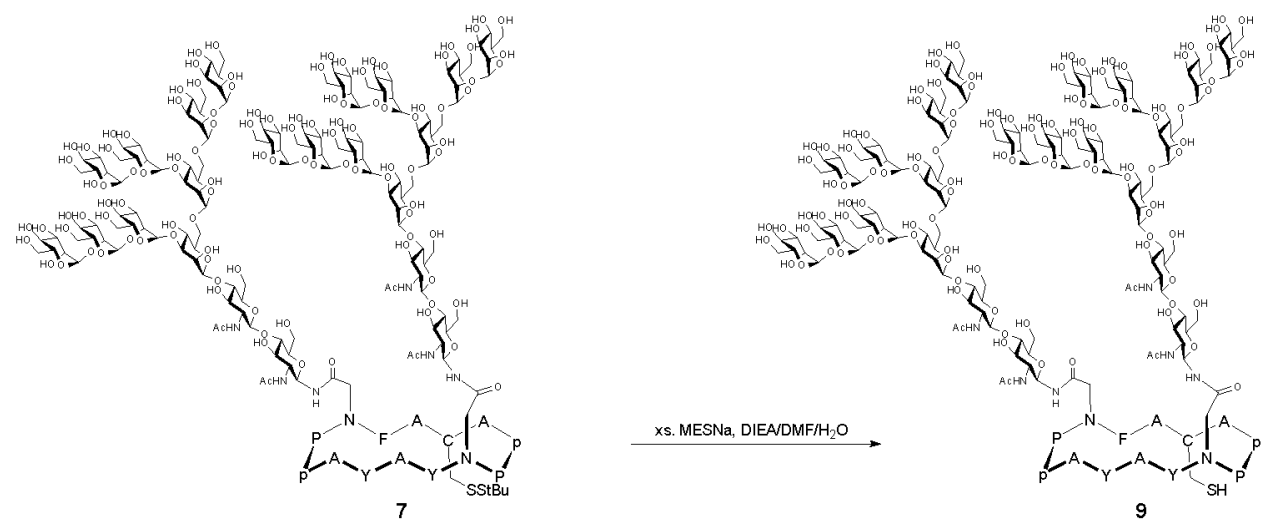

Cysteine-disulfide deprotection of 7: To a solution of $6.6 \mathrm{mg} 7(1.25 \mu \mathrm{mol})$ in $1.4 \mathrm{~mL}$ DMF and $175 \mu \mathrm{L}$ water was added $87 \mu \mathrm{L}$ DIEA. Argon was bubbled through the reaction mixture for 15 minutes and then mercaptoethane sulfonic acid, sodium salt was added (20.5 mg, .125mmol, 100 equiv.). After 9 hours, LC/MS analysis in 10-40\% B over 30 min showed $>90 \%$ conversion (product R.T. $18.3 \mathrm{~min}$ ), with a trace of mixed 7-MESNa disulfide beginning to appear (R.T. $15 \mathrm{~min}$ ). The crude reaction mixture was then injected, with minimal handling in air, onto preparative reverse-phase HPLC, using a gradient of $10-40 \% \mathrm{~B}$ over $30 \mathrm{~min}$ (see General Info for buffer composition). Product fractions were collected at 20.4 minutes and immediately shell-frozen and lyophilized. The solid product of this reaction is prone to air-oxidation and is most reliably preserved by storage under vacuum.

LC/MS of crude reaction (left), and ESI-MS of 9 (right):

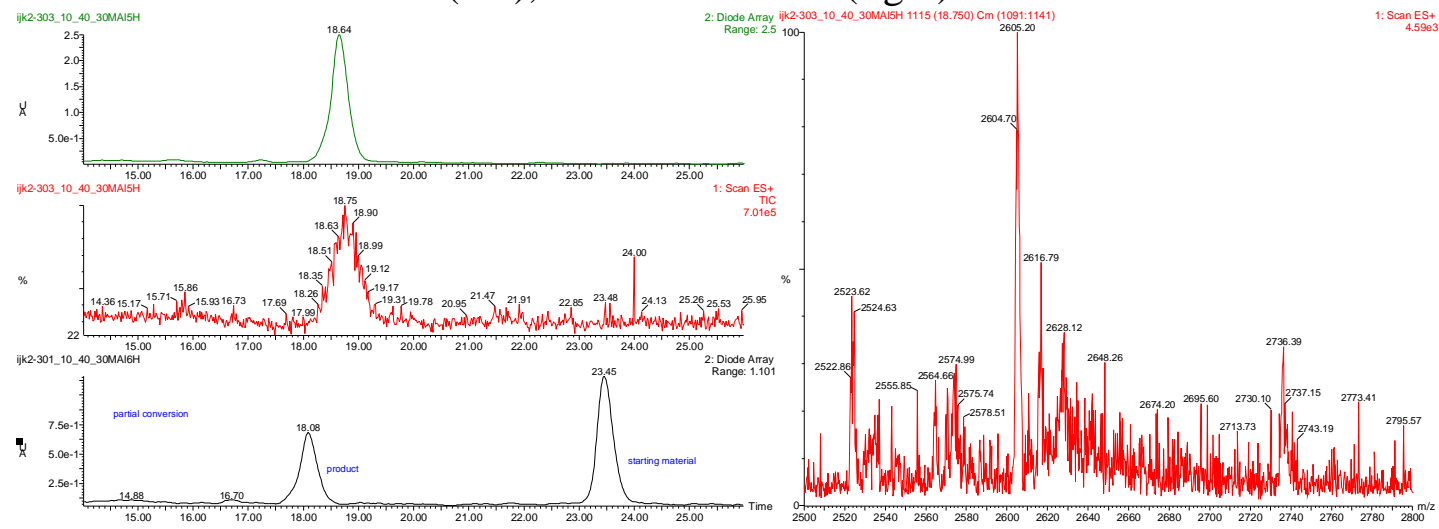


Conjugation of glycopeptide to OMPC For this study, the carrier protein used was the outer membrane protein complex (OMPC) of Neisseria meningitidis whose purification and properties have been described elsewhere $(1,2)$. Purified OMPC was activated for conjugation by reaction with sulfosuccinimidyl 4-( $N$-maleimidomethyl)-cyclohexane-1carboxylate, sSMCC (Pierce, Rockford, IL) in order to introduce a thiol-reactive maleimide group onto protein lysine residues.

Briefly, OMPC was buffered to $20 \mathrm{mM}$ HEPES, $\mathrm{pH} 7.3$, and sSMCC was added at a 10 -fold molar excess over the total Lys content. The reaction was carried out for 4-5 $\mathrm{h}$ at $4{ }^{\circ} \mathrm{C}$ in the dark after which excess reagent was removed by exhaustive dialysis against $20 \mathrm{mM}$ HEPES, pH 7.3, 2mM EDTA. The maleimide content of the derivatized OMPC was determined by quantitation of thiol consumption using $\mathrm{N}$-acetyl-cysteine. Lyophilized glycopeptide 9 was solubilized in 0.1M HEPES, pH 7.3, 2 mM EDTA at 2 $\mathrm{mg} / \mathrm{mL}$, and the free thiol content was determined by the method of Ellman using 5,5'dithionitrobenzoic acid (DTNB) (3). Glycopeptide 9 was mixed with maleimidated OMPC at a 1.5:1 molar ratio of thiol to maleimide and incubated in the dark for $17 \mathrm{hr}$ at $4^{0} \mathrm{C}$. A maleimidated OMPC-only control was prepared in parallel. Conjugate and control were treated with 2-mercaptoethanol to quench residual un-reacted maleimide groups and then exhaustively dialyzed against $20 \mathrm{mM}$ HEPES, $\mathrm{pH} 7.3,0.15 \mathrm{M} \mathrm{NaCl}$ buffer to remove residual reagents and un-reacted peptide. A final low speed centrifugation was performed to remove any aggregated product.

Protein concentration was determined by a modified Lowry assay (4), and peptide incorporation was determined by a quantitative amino acid analysis method in which the molar peptide to OMPC ratio was calculated from the value of dicarboxyethylcysteine, a unique residue released upon acid hydrolysis of the nascent peptide-OMPC bond.

Enzyme-Linked ImmunoSorbent Assay (ELISA) Maxisorp 96-well plates [NUNC Cat No. 430341] were incubated with $100 \mu 1$ per well of HIV-1 ${ }_{\text {IIIB }}$ gp160 Recombinant Viral Protein [Advanced Biotechnologies Incorporated Cat No. 14-127-050], 9-OMPC conjugate, or OMPC alone at different concentrations from $4,000 \mathrm{ng} / \mu 1$ to $31.25 \mathrm{ng} / \mu \mathrm{l}$ in phosphate buffered saline (PBS) at $4^{\circ} \mathrm{C}$ over night. Plates were washed four times with PBS containing $0.05 \%$ Tween-20 (WB) and blocked with $1 \%$ Bovine Serum Albumin (BSA) in WB for 2 hours at room temperature. Plates were washed four times with WB and $100 \mu \mathrm{l}$ per well of 2G12 monoclonal antibody [Polymun Product No. AB002] at a concentration of $1 \mu \mathrm{g} / \mathrm{ml}$ in $\mathrm{BB}$ were added and incubated for 2 hours at room temperature. Plates were washed four times with $\mathrm{WB}$ and $100 \mu 1$ per well of HRP-Goat anti Human IgG [H+L] [Bio-Rad Cat No. 172-1033] Diluted at 1:1,000 in BB were added and incubated for $1 \mathrm{hr}$ at room temperature. Plates were washed four times with WB and $100 \mu \mathrm{l}$ per well of OPD solution [DAKO, Code No. S2045] were added and incubated for 10 minutes in room temperature before stopping the reaction with $100 \mu \mathrm{l}$ per well of $0.5 \mathrm{M} \mathrm{H}_{2} \mathrm{SO}_{4}$. The plates were read at $492 \mathrm{~nm}$ for absorbance using an ELISA plate reader.

Surface plasmon resonance measurements Measurements were preformed on a BIACore 2000, and all reagents were supplied by BIACore (Piscataway, NJ) unless 
otherwise specified. Each antigen was tested for binding to 2G12 (Polymun Scientific, Vienna, Austria) in a distinct experiment. For each experiment, two flow cells of a fresh CM5 chip were activated with an EDC/NHS mixture; $5 \mu \mathrm{g} / \mathrm{mL} 2 \mathrm{G} 12$ in sodium acetate $\mathrm{pH} 5.5$ was injected over one; both flow cells were blocked with $1.0 \mathrm{M}$ ethanolamine$\mathrm{HCl} \mathrm{pH} \mathrm{8.5.} \mathrm{The} \mathrm{target} \mathrm{level} \mathrm{for} 2 \mathrm{G} 12$ immobilization was 6000 response units (RU), actual immobilizations ranged from 6015 to 6527 RU.

During each cycle, association was observed while the antigens were injected over both surfaces at $50 \mu \mathrm{L} /$ minute for 5 minutes, and dissocation was monitored for 45 minutes thereafter. Time-resolved signals from the control channel were automatically subtracted from the 2G12-immobilized channel. Antigens were tested in duplicate in successive $1: 2$ dilutions from $10 \mu \mathrm{M}$ to $0.31 \mu \mathrm{M}$. After each cycle, regeneration was performed with two 20 second pulses of $4.0 \mathrm{M} \mathrm{MgCl}_{2}$ at $60 \mu \mathrm{L} /$ minute. All experimental steps were performed under a controlled temperature of $25^{\circ} \mathrm{C}$.

\section{Abbreviations}

NHS, N-hydroxysuccinimide; EDC, (N-ethyl-N'-(3-dimethylaminopropyl)carbodiimide; RU, response unit.

\section{References}

1. Frasch, C. E.; Robbins, J. D. J. Exp. Med. 1978, 147, 629-644.

2. Marburg, S.; Jorn, D.; Tolman, R. L.; Arison, B.; McCauley, J.; Kniskern, P. J.; Hagopian, A.; Vella, P. P. J. Am. Chem. Soc. 1986, 108, 5282-5287.

3. Ellman, G. L. Arch. Biochem. Biophys. 1959, 82, 70-77.

4. Markwell, M. A.; Haas, S. M.; Bieber, L. L.; Tolbert, N. E. Anal. Biochem. 1978, 87, 206-210.

\section{Complete References 4 and 19b from manuscript}

4. Calarese, D. A.; Scanlan, C. N.; Zwick, M. B.; Deechongkit, S.; Mimura, Y.; Kunert, R.; Zhu, P.; Wormald, M. R.; Stanfield, R. L.; Roux, K. H.; Kelly, J. W.; Rudd, P. M.; Dwek, R. A.; Katinger, H.; Burton, D. R.; Wilson, I. A. Science 2003, 300, 2065-2071.

19b. Joyce, J. G.; Abeygunawardana, C.; Xu, Q.; Cook, J. C.; Hepler, R.; Przysiecki, C. T.; Grimm, K. M.; Roper, K.; Yu Ip, C. C.; Cope, L.; Montgomery, D.; Chang, M.; Campie, S.; Brown, M.; McNeely, T. B.; Zorman, J.; Maira-Litrán, T.; Pier, G. B.; Keller, P. M.; Jansen, K. U. Mark, G. E. Carbohydrate Res. 2003, 338, 903-922. 